The effects of human capital, R\&D and firm's innovation on patents: A panel study on Dutch food firms

Peer-reviewed author version

VANCAUTEREN, Mark (2018) The effects of human capital, R\&D and firm's innovation on patents: A panel study on Dutch food firms. In: JOURNAL OF TECHNOLOGY TRANSFER, 43(4), p. 901-922.

DOI: $10.1007 / \mathrm{s} 10961-016-9523-2$

Handle: http://hdl.handle.net/1942/22578 


\title{
The effects of human capital, R\&D and firm's innovation on patents: A panel study on Dutch food firms
}

\author{
Author details: \\ Mark Vancauteren, affiliation: Hasselt University and Statistics Netherlands. \\ phone: +3211268664 \\ Address: Universiteit Hasselt, Campus Diepenbeek, Agoralaan Gebouw D, BE-3590 \\ Diepenbeek, Belgium
}

Acknowledgement: We thank participants of the 146th EAAE Seminar on "Technology transfer as a driver of innovative entrepreneurship in agriculture and the agri-food industry" held in Chania (15-16/072015).

Abstract: This paper analyzes the determinants of a firm's patent output using data for 20002008 which enables us to take into account the role of workers' skills, other firm's innovation (process, product, organization) as well as other important firm characteristics including unobserved firm-level heterogeneity.

The main results, robust across specifications, suggest a positive and significant effect of process innovation and workers' skills on patent counts while product innovation becomes an important determinant in explaining forward citations. The inclusion of unobserved heterogeneity is essential in the analysis and seems to affect our results.

Key Words: Innovation, Patents, patent production functions

JEL Codes: C33, D22, 030

\section{Introduction}

Research on knowledge-based firms have identified various conclusive drivers that explain the firm's patent output. Usually, these drivers (known as technology push and demand pull effects) that have been identified in the literature (e.g., see Hall, 2011 for recent references) include R\&D (process, product, intra - and extramural), human capital, competitive effects and economies of scope in addition to geographical and industry-specific characteristics. Some literature has also emphasized the persistence of patenting whereby the knowledge covered by past patents can be used as an input to further patenting (see, for example Hall and Harhoff, 2012). When looking at data characteristics, another important stylized fact is that given the innovative intensity of a firm, some firms decide to apply for patents while others do not (see Hall et al., 2013 for references). As a result, the skewness nature of patent statistics is prevalent in many studies. In particular, it is well known that a large share of patents is applied for by only a small number of firms (see for example, Licht and Zoz, 2000; Vancauteren et al., 2015).

Based on several variants of patent data models, a preponderance of innovation studies generally find that patents increase with R\&D while the size-innovation and competitioninnovation relationships often yield contrasting results. This is not surprising since theoretical models also show different predictions on the relationship between innovation, on the one hand, and size and competition, on the other. ${ }^{1}$ Therefore, some major aspects of the results on this type of analysis is the wide variety in market and technological characteristics that are embedded in theoretical models, measurement of size and competition variables and model

\footnotetext{
${ }^{1}$ For instance, on the role of competition, the seminal paper of Aghion et al. (2005) provide theoretical and empirical support for an inverted-U relationship between innovation (patents) and competition (Lerner index). The explanation of this relationship emphasizes that the escape competition effect tends to dominate for lower levels of competition whereas the Schumpeterian effect tends to dominate at higher levels of competition. However, a recent paper by Correa (2012) finds a negligible inverted U-shape when controlling for structural breaks using the Aghion et al. data.
} 
specification (panel data, cross-section, dynamics, etc.) which makes it difficult to identify consensus effects.

The main purpose of this paper is to analyze the determinants that explain the firm-level patent output in the Dutch food industry. As emphasized by Peeters and van Pottelsberghe (2006), the analysis explicitly takes into account the fact that (i) patents rather than other innovation outputs are used and (ii) that we particularly apply this analysis to the food processing sector. While most studies are conclusive about the economic valuation of patents (e.g., Bloom and Van Reenen, 2002; Sampath and Ziedonis, 2004; Hall and Harhoff, 2012; Hall et al., 2013)2 the motivation of this study is to provide more insights into the patenting behavior of firms within the food industry. More specifically, we explain firm-level patent propensities by determinants that are believed to be empirically important sources where we distinguish between the role of a workers' skills, intrinsic firm's innovation as well as other important firm characteristics including unobserved firm-level heterogeneity. Do firms patent because they employ a higher skilled workforce or is the firm itself intrinsically more innovative? What about the role of other firm's characteristics such as, size, ownership structure, competition? Do we still observe large unobserved heterogeneity once we control for other subsumed characteristics? How are our results affected when we control for the "quality" of patenting?

Selecting the Dutch food processing industry provides an interesting case study as it contains features that are also common to other industries. By focusing on one industry, our understanding of what factor may or may not be important when explaining the patent behavior of firms and in particular, the contribution of innovation disentangled from what is originated from workers versus observed and unobserved firm characteristics, is also increased.

The data on innovation is extracted from the (R\&D) surveys, the Community Innovation Surveys, a matched employee-employers database and a database that matches the entire population of patents to firms for the period 2000-2008. Interesting is that the patent database distinguished Dutch patents and EPO patents. The double counting problem, namely that Dutch (and other country-group defined patents) may also count as an EPO patent is cleaned for. The data is available from Statistics Netherlands (and is therefore applicable to Dutch food firms).

The comprehensiveness of the dataset allow us to contribute to the literature in various ways. First, we take into account sample selection bias by including firms that do not necessarily report their R\&D efforts. As might be expected, larger patenting firms also tend to report R\&D more often. Our data shows that about 10 percent of the patenting firms can be regarded as non$R \& D$ reporting firms throughout the entire sample period. However, due to the nature of the data we find among the R\&D reporting, patenting firms missing values in some of the accompanying years. Given their involvement with patenting, the exclusion of these firm-level observations could result in biased estimates when explaining firm-level patents behavior. To correct for this potential problem, we adopt a two-step sample selection model applied to panel data with unobserved heterogeneity.

Second, given that we can control for the presence of innovation, our analysis provides more insights on the determinants of a firm's patent propensity. The availability of R\&D as a proxy for innovation enables us to assess the determinants of a firm's decision to patent as well as the level of patenting conditional on R\&D appropriation. However, one particular characteristic that is inherent to the food industry is that, in addition to R\&D, other innovative characteristics may be equally important in explaining differences in patent propensities. By merging data at the firm-level from different sources, we also take a closer look at the role of other firm-level characteristics that may affect the number of patents. We pay specific attention to the role of skilled labor, firm's innovative activities (products, process and organizational innovation), a firm's ownership structure (foreign, group membership), competition (Herfindahl) and economies of scope (range of goods). In addition, the richness of the panel data set enables us to control for firm-specific unobserved heterogeneity into innovation relating to factors such as, a

\footnotetext{
${ }^{2}$ To the extent that we can still learn much more about the size and competitive effects on innovation, an important finding is that patent propensities increases with firm size significantly, because larger firms can better diversity their fixed costs of patent application over a large number of patents (Nagaoka, et al., 2010)
} 
firms's attitude towards patenting as well as other firm's characteristics. As a result, our study corroborates with a few existing studies of patenting and innovation at the firm-level while also controlling for the presence for other innovative measures (e.g., Brouwer and Kleinknecht, 1999; Balasubramanian and Sivadan, 2011; Moser, 2012; Hall et al., 2013). By accounting for all these (observed and unobserved) characteristics, we are in a better position to assess the true determinants of a firm's patenting behavior. Turning to the empirical evidence on the effects of various firm characteristics on patent propensities, no in-depth patent analysis is carried out on the effects of various firm characteristics at a more detailed level whereby determinants such as $R \& D$, other forms of innovation (product, process, organizational), competition, scope economies, skills and ownership structure are incorporated in panel data framework.

A third way in which we depart from the literature on innovation and patenting is the econometric treatment where take into account that the distribution of patents is usually highly skewed reflecting overdispersion. The consequence of this feature is that in many application using patent count data, distribution assumption according to Poisson, Negative binomial or any other popular discrete distributions may be wrongly specified if one does not deal with these issues. Zero-inflated count models takes these properties into account which we extend to a data panel analysis taking into account the unobserved heterogeneity.

The remainder of the paper is organized as follows. In section 2 we review related literature. In section 3 we provide an overview of the data as well as characteristics of patenting and nonpatenting firms. Section 4 discusses the estimation method. Section 5 reports the results using several specifications of patent equations, and investigating the impact of R\&D, product/process innovation, and other characteristics. Section 6 concludes.

\section{Innovation in the food industry and literature review}

This section provides a short overview of innovation studies in the food processing industry. By doing so, it increases our understanding of which factors deemed to be important in the food processing industry. While there is a limited work on analyzing the determinants of firm-level patent propensities in the food processing industry, this industry presents features that are common to other industries, as well. Several studies dealing with innovation in the food industry (see e.g. amongst others, Karantininis et al., 2011; Arundel and Kabla, 1998; Menrad, 2004; Peneder, 2007, Sanyang et al., 2009) point out to a low share of R\&D and patented inventions. ${ }^{3}$ Also the European Confederation of food and drink industry (CIAA) concluded that more innovation is needed so to cope with EU competitiveness (CIAA, 2010). One convincing reason why this industry is characterized by a relatively low innovation intensity is, according to Weiss and Wittkopp (2005) and Dobson and Chakraborty (2009), that increased power by retailers may decrease prices reducing product variety and innovation efforts by agri-food firms. Weiss and Wittkopp (2005) further empirically verify that this negative price effect is mitigated when manufactures have market power. In an EU-wide study, Wijnands et al. (2007) note that food innovation is, in comparison to other industrial sectors, less driven by radical, technologicaldriven inventions. Rather, food innovation is oriented towards process technology, marketing and organization, and new product variations of existing products.

While innovation activities in the food industry can be analyzed on different levels, using different methodological approaches, one of the other characteristics is that a high relevance of product innovation is found among manufacturers. Product innovation can contribute to deterring entry. The proliferation of brands, a typical feature in this industry, and product differentiation is likely to discourage entry, according to Alfranca et al. (2002). In addition, several studies have shown that product innovation can be characterized as incremental

\footnotetext{
${ }^{3}$ We refer to the CIAA (2010) for cross-country comparison of R\&D investment levels and cross -industry comparisons of output innovation across world markets.
} 
innovation or even imitations (see Menrad, 2004, for further references) or through patent licensing (Rubenstein , 2003).

With specific reference to the Netherlands, let start with a comparative review using aggregated data on patents for the food sectors across major countries. In an international benchmarking study on innovation in the food processing sector, van Galen et al. (2013) show that the number of patent applications in comparison to other major European countries amounts the highest to $9 \%$ of all patent applications in the world. ${ }^{4}$ Despite the fact that R\&D expenditures in this sector are low compared to other sectors, Dutch R\&D expenditures, expressed as a percentage of turnover, ranged between 40 to 50 percent ranking at the top among major EU countries. In addition to R\&D, the Dutch food industry scores less on innovation measures like "new product" and "organizational" but attains a high score on "process" innovation where Germany takes a leading role. As a result, the Dutch food sector is rather characterized by technological innovation given the high prevalence of patenting activities and the focus on process innovation. Focusing on sectors within the Netherlands, data on total patent applications during the period 2000-2006 (CBS, 2010) show that patent applications in the food processing industry amounts to $5 \%$ of all patent applications. This share ranks at the top 5 of shares within the manufacturing sector whereby the sector in audio, video and telecommunications accounts for $48 \%$ of all patent applications during that same period.

Since innovation is of less central importance in the food processing sector, the control for non-innovative determinants is therefore essential in the analysis. A study that relates patent counts to various firm determinants is the work of Gopinath and Vasavada (1999). Using data for US food processing firms, the authors look to what extent R\&D, market share and the number of subsidiaries affect patent counts. Results show that both firm- and industry wide R\&D and market power increase patent count propensities. Alfranca et al. (2002), who analyze US patent counts collected from the 103 largest food \& beverage firms around the world over the period 1997-2004, find that the patent data exhibit an auto- regressive process confirming the successbreeds-success hypothesis in the innovation literature. A more recent study is Alarcon and Polonio (2014) for a panel of 449 Spanish food firms for the period 1998-2008. Breaking down their sample into large versus small firms, it is shown that internal rather than external R\&D is positive associated with patenting in the case of small firms while the opposite effect is found for large firms. Other determinants that seem to play an important role are technological cooperation with suppliers, size (proxied by the number of employees) and the export intensity, but only in the case of large firms.

\section{Data}

Our data consists of an unbalanced panel of 91 firms, collected from different data sources, representing the total population of firms engaged in patenting. We refer to firms that are located in the Netherlands and data is collected over the period 2000-2008. The database includes 91 firms that have applied for at least one patent during the years 2000-2008. Within the food processing industry, the patenting firms represent 99 percent of all patent applications during this period. These patenting firms are ultimate parent firms located in the Netherlands which are matched to the entire population of patents applied for at the European Patent Office and/or the Dutch Patent Centre ("Nederlands Octrooicentrum") during the period 2000-2008. Interesting is that the patent database distinguishes Dutch patents and EPO patents. The double counting problem, namely that Dutch (and other country-group defined patents) may also count as an EPO patent is cleaned for. In case patents were applied for in name of possible subsidiaries in the Netherlands, these where then counted to the ultimate parent of the firm.

\footnotetext{
${ }^{4}$ The patent data in the study was measured according to the international patent classification that pertains to "food and food stuff", "baking" and "butchering". The other EU countries taken in the analysis include Denmark, France, Germany, Italy, Poland, Spain, the Netherlands, UK and USA.
} 
Because the purpose of this study is to examine the determinants of patents, we first need reliable data of R\&D investments. ${ }^{5}$ We used two complementary data sources collected by Statistics Netherlands. First, we extract R\&D data from the Community Innovation Surveys which are collected in the even years of our sample period 2000-2008. For the odd years, we append the R\&D data using the R\&D surveys. Important to note is that the stratified populations of firms in the R\&D surveys are much smaller than those populations being defined in the CIS waves. We return to the implication of this issue below.

Table I presents some descriptive statistics on the R\&D and patent behavior of the sampled firms. The column "R\&D reported" shows the sample of firms with R\&D reported values in any of the sample years, while the column "R\&D not reported" presents the sample of firms where $R \& D$ is reported as missing throughout the sample period. The table shows that firms that are engaged in both EPO and Dutch patenting mostly report R\&D. This group of firms represents 44 out of a total of 91 patenting firms and amounts to the majority of EPO patents.

Table I: Innovation Data Sample

\begin{tabular}{|l|l|l|l|l|l|}
\hline Variables & $\begin{array}{l}\text { R\&D } \\
\text { reported }\end{array}$ & $\begin{array}{l}\text { R\&D non- } \\
\text { reported }\end{array}$ & Total firms & $\begin{array}{l}\text { EPO } \\
\text { patents }\end{array}$ & $\begin{array}{l}\text { Dutch } \\
\text { patents }\end{array}$ \\
\hline $\begin{array}{l}\text { Total firm sample of } \\
\text { which: }\end{array}$ & 68 & 23 & 91 & 2455 & 448 \\
\hline EPO patents & 14 & 5 & 19 & 414 & 0 \\
\hline Dutch patent firms & 21 & 7 & 28 & 0 & 139 \\
\hline $\begin{array}{l}\text { EPO \& Dutch patent } \\
\text { firms }\end{array}$ & 33 & 11 & 44 & 2041 & 309 \\
\hline & & & & & \\
\hline
\end{tabular}

Data on the number of employees, ownership structure, the number of subsidiaries, a firm's age and the number of industry segments is taken from the general business register (in Dutch "Algemeen Bedrijven Register," ABR). Data on human capital is extracted from an employeeemployer matched database sourced from the Social Statistics Database also available at Statistics Netherlands.

The summary statistics of our key variables are shown in the Appendix according to three sub-sample groups: EPO \& Dutch patenting firms, Dutch only patenting firms and EPO only patenting firms. The statistics are based on the total sample of firms from the period 2000 to 2008. The average firm in our sample applies approximately for 1 Dutch and 7 EPO patents a year, spends on average 8 million R\&D, 76\% of the firms are engaged in product innovation, $75 \%$ of the firms engage in process innovation while $57 \%$ of the sampled firms do organizational innovation. On average, 1330 employees are employed, with an average wage bill of 57 million euros. The annual Herfindahl index is equal to $1.8 \%, 34 \%$ of the firms are foreign owned, is involved in approximately 3 sectors, has approximately 6 firms under control and the ratio high versus low skills amounts to 1.15 . We note that the standard deviation suggests considerable variability in the data series and the distribution of the patent data series is quite skewed.

\section{Empirical Analysis}

Our empirical analysis is divided in two parts. As discussed previously, R\&D is missing or not reported for a number of observations. First, we begin with a dynamic type 2 Tobit model which we extend to a panel data context, following Wooldridge $(1995,2005)$, which enables us to exploit the unobserved heterogeneity at the individual level. This modelling approach takes into account that non-reported R\&D firms are engaged in patenting activities. In the second part of

\footnotetext{
${ }^{5}$ In the subsection 4.3. we discuss in more detail the construction for some of the variables (human capital, competition, size).
} 
the model, we explain the propensity to patent. We allow for a panel data count model that correct for zero inflation. ${ }^{6}$

\subsection{R\&D equation}

To model R\&D expenditure we adopt a dynamic type 2 Tobit model ${ }^{7}$ with censoring consisting of two equations, where one is a Probit equation determining the probability that a firm reports its R\&D expenditure and the other equation is a censored regression explaining the amount of $R \& D$ invested, which is censored at zero, corresponding to zero R\&D.

The selection equation can be specified by a binary variable REP_\{it\} that is equal to one when $R \& D$ is reported by firm i in year $t$ and zero otherwise. That is,

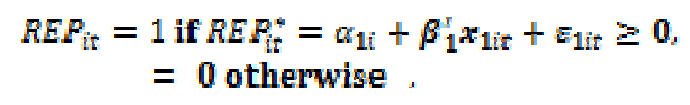

where $R E P_{i t}$ is the corresponding latent variable, $\alpha_{\mathbf{i}}$ represents the firm-specific heterogeneity, $\boldsymbol{x}_{1 i t}$ is a first vector of (firm-related) independent variables, and $\boldsymbol{\varepsilon}_{\boldsymbol{1 i t}}$ is an error term. The vector $\boldsymbol{\beta}_{\mathbf{1}}$ is a vector with unknown parameters. We observe $\left(R E P_{i t}, R E P_{i t} * R \& D_{i t}\right)$ where observing $(0,0)$ means that $R \& D_{i t}$ is unobserved, because it is not reported, while observing $(1,0)$ means that $R \& D$ is reported to be equal to zero.

Firm i's R\&D expenditure per employee at time $t$ is modeled as:

$$
\begin{gathered}
R \& D_{i t}=R \& D_{i t}^{*} \text { if } R \& D_{i t}^{*}=\alpha_{2 i}+\beta_{2}^{r} x_{2 i t}+\varepsilon_{2 i t} \geq 0 . \\
=0 \text { otherwise. }
\end{gathered}
$$

where $R \& D_{i \pm}^{*}$ is a latent variable representing the firm's R\&D effort, $\alpha_{\mathbf{3 i}}$ reflects the firm-specific unobserved heterogeneity, $\boldsymbol{x}_{\boldsymbol{z} i t}$ is a vector of independent variables representing firm characteristics, and $\varepsilon_{2 i t}$ is a random error; $\boldsymbol{\beta}_{2}$ is a vector with unknown coefficients. The vector $\boldsymbol{x}_{1 \boldsymbol{i} t}$ is not equal to $\boldsymbol{x}_{\mathbf{z} i t}$, i.e., we allow for an exclusion restriction, which is typical for a sample selection model.

In the dynamic type 2 Tobit model, the firm-specific unobserved heterogeneity is developed by Wooldridge $(1995,2005)$. We assume the distribution of the unobserved individual effects $\left(\alpha_{1 i}\right.$ and $\alpha_{2 i}$ ) to be modeled as follows,

$$
\begin{gathered}
\alpha_{1}=\alpha_{10}+\delta_{1}^{r} \bar{x}_{1 i}+\xi_{1 i}, \\
\alpha_{2 i}=\alpha_{20}+\delta_{2}^{r} \bar{x}_{2 i}+\xi_{2 i} .
\end{gathered}
$$

where $\alpha_{10}$ and $\alpha_{20}$ are constants, $\bar{x}_{1 \mathrm{i}}$ and $\bar{x}_{2 \mathrm{i}}$ are vectors including the time averages of the variables included in $\boldsymbol{x}_{\mathbf{1 i t}}$ and $\boldsymbol{x}_{\mathbf{z} i t}, \boldsymbol{\delta}_{\mathbf{1}}$ and $\boldsymbol{\delta}_{\mathbf{2}}$ are the corresponding (vectors of) coefficients to be estimated, and $\bar{\xi}_{\mathbf{1 i}}$ and $\bar{\xi}_{\mathbf{2} i}$ may be interpreted as unobserved heterogeneity that is uncorrelated with the regressors. To estimate this unobserved heterogeneity, we adapt a twostep estimation method proposed by Wooldridge (1995) for sample selection in panel data models. ${ }^{8}$

\footnotetext{
${ }^{6}$ The materials that follow in this section is heavily drawn from Vancauteren et al. (2015).

${ }^{7}$ See, for example, Amemiya (1985) on Tobit models.

${ }^{8}$ Note, we follow Dustmann and Rochina-Barrachina (2007) and use a probit equation in the first step and an OLS estimation in the second step equation.
} 
We include in the vector $\boldsymbol{x}_{\mathbf{z} i t}$ the following independent variables to explain $R \& D$ expenditure: the number of employees ("employment") measured in logs, competitive pressure ("competition") measured in logs, a variable indicating the number of domestic firms under control ("number of firms"), the number of 3-digit industry segments measured in logs ("number of activities"), a yearly dummy variable equals 1 if the firm 's headquarter is located abroad ("foreign"), firm's age in logs, three dummy variables indicating whether the firm has been engaged in product, process and organizational innovation, a variable capturing a firm's endowment of human capital ("skills"), and yearly dummies. We include in the vector $\boldsymbol{x}_{\mathbf{1 i t}}$, the same variables as in vector $\boldsymbol{x}_{\mathbf{z i t}}$ but replace the "number of firms" and "foreign" with a variable reflecting whether the firm is part of a group ("group"). To measure competition, we use the Herfindahl index of industrial concentration being the sum of the quadratic relative firms sizes based on the number of employees. We return to a more detailed discussion in subsection 4.3.

\subsection{The Patent Equation}

The next part of the model explains the innovation output measured by the number of patents filed in a given year. The discreteness of patent data motivates the use of a count model. To present the model, we first introduce

$P\left(y, \lambda_{i \mathrm{t}}\right) \equiv \frac{\exp \left(-\lambda_{\mathrm{it}}\right) \lambda_{\mathrm{it}}^{y}}{y !}, \quad y \in\{0,1,2, \ldots\}$

where $\lambda_{i t}$ is the Poisson distribution parameter. Let $P A T_{i t}$ be the number of patents. We model $\ln \lambda_{\text {it }}$ as

$$
\ln \lambda_{\mathrm{it}}=\alpha_{\mathrm{g} i}+\delta_{\mathrm{3}} R \& D_{i, \mathrm{t}-1}+\beta_{3}^{s} x_{\mathrm{git}}
$$

where $\alpha_{3 i}$ is a time-invariant unobserved firm-effect, $\boldsymbol{x}_{\mathbf{3} i t}$ is the vector of independent variables, and $\delta_{3}, \boldsymbol{\beta}_{\mathbf{3}}$ include the unknown parameters. The time-invariant unobserved firmeffects $\alpha_{g i}$ is assumed to be standard normally distributed (conditionally on $R \& D_{i, t-1}$ and $x_{3 i x}$ ). As in equations (3-4), and following Wooldridge (2005), we model the unobserved heterogeneity as being dependent on the average of the continuously distributed explanatory variables with additional random effects that are uncorrelated with the regressors. In case the firm's $\mathbb{R} \& D_{i, t-1}$ is unobserved, we take its predicted value from the model described in the previous subsection. We consider $\boldsymbol{x}_{\mathbf{3} i t}$ the same as $\boldsymbol{x}_{\mathbf{2} i t}$ in equation (2) as motivated by previous patent studies as we discuss in the next section.

In addition, the Poisson model may need to be adapted to a corresponding with-zeros model in case of excess zeroes, meaning more zero counts in the data than predicted by a Poisson model. Then, the hurdle or two-part model and the zero inflated model are two commonly used count models taking the excess of zeros into account. First, we focus on the panel version of the hurdle model; similar issues arise for the zero-inflated model. We specify

$$
\operatorname{Pr}\left(P A T_{\text {it }}=0\right)=\left(1-p_{\text {it }}\right) P\left(0, \lambda_{i t}\right), \operatorname{Pr}\left(P A T_{\text {it }}=y\right)=p_{\text {it }} P\left(y, \lambda_{\text {it }}\right), \quad y \geq 1
$$

where $p_{i t}$ represent the probability that firm i did pass a treshold with positive counts. Thus conditional on the event that the treshold is crossed, the distribution of positive patents outcomes follow the Poisson distribution, see Cameron and Trivedi (2013). Thus, in a hurdle model, the decision to patent is usually made on the basis of a first invention and the decision to apply for additional patentable inventions is based on the outcomes of this first decision. So, we might expect different decision criteria concerning the first patent and additional patents.

In case the data generating process follows a zero inflated distribution, the model treats the zero counts as coming from a distinct process due to, for example, firms that never engaging in 
the patent activity. The zero-inflated model can therefore be seen as a mixture model having two classes. We specify,

$\operatorname{Pr}\left(\llbracket P A T \rrbracket_{1} i t=\left(1-p_{1} i t\right)+p_{1} i t P\left(\mathbf{0}, \lambda_{1} i t\right), \operatorname{Pr}\left(\llbracket P A T \rrbracket_{1} i t=y\right)=p_{1} i t P\left(y, \lambda_{1} i t\right), \quad y \geq 1\right.$

(8)

in that case, $1-p_{\text {it }}$ is the zero inflation parameter that captures the probability of extra zeros, and $P\left(0, \lambda_{i t}\right)$ is the probability distribution of the Poisson count model. Excess zeros, or zero inflation, occur by definition whenever $1-p_{\text {it }}>\mathbf{0}$. More specifically, a zero-inflated count model considers a probability distribution that allows for modelling two separate zeros:(i) a structural (inflated) zero resulting from a binary process, for example, never participating in patent activities, and (ii) an incidental zero as a realization of the count process of number of patents. ${ }^{9}$ We model the probability $p_{i t}$ as,

$$
\text { logit } p_{i t}=\alpha_{4 i}+\delta_{4} R \& D_{i, t-1}+\beta_{4}^{x} x_{4 i t} \text {. }
$$

where $\alpha_{\mathbf{a}_{\mathrm{i}}}$ is the unobserved firm-effect (which we define similarly like $\alpha_{\mathbf{3}}$ using the Wooldridge approach), $\boldsymbol{x}_{\mathbf{A i t}}$ (which we also set to $x_{\mathbf{s}}$ ) is the vector of independent variables and $\sigma_{\mathbf{A}}, \boldsymbol{\beta}_{4}$ include the unknown parameters. To fit both the pooled hurdle and zero inflated models with random effects, we adopt the approach from Min and Agresti (2005) where we allow for possible correlation between the unobserved heterogeneity. The Poisson model (6) assumes equality of the mean and the variance in the distribution of the dependent variable. As this property may need to be properly handled according to the data, we will also consider a negative binomial distribution in (5).

\subsection{Determining innovation}

A clear contribution in understanding the major determinants that drive innovation in the food industry has been made by Grunert et al. (1997) and Avermaete et al. (2004). While the choice of the above mentioned variables is motivated by the vast empirical literature which looks into innovation determinants (see Vancauteren et al., 2015, for a recent discussion), the specificity, however, of each sector is important as each one approaches innovation from different technological perspectives (Pavitt, 1984). For measuring innovation we consider the number of patent applications in line with a limited number of agri-food studies (Gopintah and Vasavada, 1999; Rubenstein, 2003; Alfranca et al., 2004; Alarcon and Polonio, 2014) which we relate to R\&D and, amongst other determinants, to dichotomous variables which look at whether companies innovate in product, process and/or organizational innovation. However, a good part of the agri-food literature reviewed (amongst others, Garcia and Burns, 1999; Brewin et al., 2009; de Jong and Vermeulen, 2006; Avermaete et al., 2004) consider these dichotomous variables rather as proxies for innovation performance measures which in turn are, usually, modelled as a function of several input dependent variables. This study nonetheless does not follow this latter approach but instead relate the actual, observed patenting activities to innovative performance measures, controlling for R\&D, human capital and various other factors. The availability of these data allows us to assess the determinants on patent propensities conditional on innovating. We believe that patenting behavior increases for innovative firms which is captured by R\&D, product -, process- and organizational innovation as well as human capital. To our knowledge, this is the first time that this type of analysis has been conducted with specific reference to the agri-food industry; although other studies have considered the effect of innovation output measures but then on the decision to patent, rather than its intensity, and in a limited panel framework (Hall et al., 2013) or cross section (Brouwer and Kleinknecht, 1999; Pajak, 2010).

\footnotetext{
${ }^{9}$ For a detailed discussion on zero-inflated count models we refer to Cameron and Trivedi, 2013.
} 
Concerning some other determinants, we also include the size of the firm, measured by the number of employees, and is expected to be positively correlated with innovation, following Schumpeter. Based on an empirical review of food innovation studies that have looked into firm size effects (e.g., Alfranca et al., 2014; Huiban and Boushina, 1998; Karantininis et al., 2011) confirm a positive relationship. The economies of scope are also positively related to innovation because it lowers the risk portfolio by diversifying innovation projects across product lines. We capture scope economies by the number of domestic firms ("number of firms") and the number of industry segments ("number of activities") which corresponds to the number of different 4digit NACE food sectors in which the firm is involved. In this sense Acosta et al. (2009) point out that technological opportunities within and outside food industries may be substantial higher if firms diversify and look for external channels to commercialize the innovation and/or inventions.

It has been hypothesized that an important factor that explains foreign direct investment is a firm's inventive activity. We include an annual dummy variable "foreign," representing whether the firm is controlled by a foreign firm. The question whether foreign controlled firms invest more or less in innovation remains unanswered. For instance, some research on the R\&D activities of foreign controlled firms finds evidence that these firms invest less in innovation than domestic firms for the reason that these firms have better access to innovation endowments from the multinational enterprise and other subsidiaries (Un and Cuervo-Cazurra, 2008). On the other hand, these firms may also have better access to capital financing which may induce the subsidiary to increase their innovation, which is also confirmed by a number of empirical studies (see the review in Narula and Zanfei, 2005; Un and Cuervo-Cazurra, 2008).

We also take into account how competitive pressures ("competition") affect the firm's innovation. We measure the level of competition using a Herfindahl index of industrial concentration being the sum of the quadratic relative firm-sizes,

$$
H_{t}=\sum_{j \in s_{t}}\left(\frac{\text { employees }_{j t}}{\text { employees }}\right)^{2}
$$

where $s_{t}$ is the set of the sampled food firms at time t. The variable "competition," defined as $\left(1 / H_{t}\right)$, measures the degree of competition firm i faces at time t. From a strategic point of view, it has been noted that food firms are driven to innovate and differentiate their products by the need to maintain their competitive advantage through market orientation (Batterink et al., 2006), from retailers (Weiss and Wittkopp, 2005) and their own direct competitors (Gopinath and Vasadava, 1999; Brewin et al., 2009). These above mentioned empirical studies point towards a decreasing effect of competition on innovation. However, we note that studies on the relationship between competition and innovation measured by patents and R\&D in the food sector is scarce. ${ }^{10}$

As a final control, we also take into account the importance of human capital. We refer to human capital as a form of a "capability" that finds its source from knowledge, skills, workers diversity, training, absorptive knowledge and all other forms of knowledge driver capacities. In the management literature, these underlying capabilities refer to knowledge capabilities which refer to deeper attributes which are often not directly observable or measurable. A recent paper by Sutton (2012) focuses on internal factors which can cause different performance levels across firms. More specifically, this research paper highlights firm capabilities, which can be defined as the working practices or know-how that is captured by a group of people who belong to the company. Providing the firms' human capital with the necessary training, or attracting more skilled employees is one way in which firm capabilities can be acquired. Another, more indirect

\footnotetext{
${ }^{10}$ We did not include a market share based on sales data because of data constraints. In the Tobit II R\&D sample selection equations and the patent equation, we employ variables that are extracted from the "General Business Register" (Statistics Netherlands) and are recorded for each firm located in the Netherlands. Sales data are available from the Statistics of Finance of Enterprises and are only available for a smaller selection of firms.
} 
way, is through side effects that result from networking with other firms (Van Beveren \& Vanormelingen, 2014). Taking into account workforce characteristics like gender, wages, age, experience, training, and education, the general consensus is that more skilled labor appears to be beneficial for innovation (see Galilie and Legros, 2012, for recent evidence on French manufacturing firms; Huiban and Boushima, 1998, for French food firms; and Avermaete et al., 2004, for EU wide food firms). The novelty of distinguishing between the role of workers' skills and other forms of internal and external innovation that can be acquired by the firm, enables us to understand what factor may or may not be important when explaining the patent behavior of firm; in particular, the contribution of innovation disentangled from what is originated from worker capabilities versus other forms of firms' innovative characteristics. Our approach of measuring human capital is based on the concept of knowledgeable workers (see Horwitz et al., 2003 for a literature review on this categorization), where we rely on classifying jobs into lowto high-paid level classifications according to certain threshold values based on the entire wage distribution (see Dobbelaere and Vancauteren, 2015, for further details on measurement and an application of this approach on productivity effects). On the basis of this approach, we classify employees as having a high-paid job if their wage is in the 81th percentile or higher of all registered jobs by age category and the NACE 2-digit food processing industry and a low-paid job if their wage is at or below the 30th wage percentile. Human capital ("high/low skills") is being measured being the ratio of the total number of all high and low paid jobs by firm.

\section{Estimation Results}

\subsection{The R\&D sample selection equation}

In modelling the determinants of R\&D expenditure, three models where estimated taking into account sample selection, see Table II. In the first two columns, we present the results of a model with the individual effects $\alpha_{\mathbf{1}}$ and $\alpha_{\mathbf{z} i}$ set equal to zero, using pooled data. The third and fourth column shows the results of the model with a partial unobserved heterogeneity where we set the individual effects $\xi_{i}$ equal to zero such that the remaining unobserved heterogeneity is subsumed in the error $\varepsilon_{i}$. The fifth column is the most general model including the entire unobserved heterogeneity. We used the specification of the third column to calculate the inverse Mills Ratios.

We first focus on the most general model (column 5). Firm size has a negative and significant effect on R\&D intensity. The result relating a negative relationship between R\&D efforts and employment can be reconciled with Demsetz (1969) stating that competition among small firms may actually produce greater research and innovation. It is important to note that our results from the log-linear model do agree with the finding that larger firms do significantly spend more on R\&D in levels rather than its intensity. Among the other controls, we find that less competitive firms do more R\&D suggesting that a rise in the market share of a firm increases its R\&D efforts. This finding also agree with the findings of some of the above mentioned studies: food firms behave less competitive in the food sector. One of the underlying claims is that food firms behave rather monopolistic (and accrue profits) in order to make the necessary innovations investments.

Looking at the impact of other forms of innovation on $R \& D$, the results indicate that both process innovation and human capital is positively related to R\&D intensities. Therefore, especially process innovation, and not product or organizational innovation, is more likely to be associated with developing new R\&D related technology. Our finding on human capital and its impact on R\&D is in line with the results obtained by Huiban and Boushima (1998) and Avermaete et al. (2004) for its impact on innovation propensities for the food industry. We note that the work by Adams et al. (2003) and Kanwar and Everson (2003) applied to the broader industrial sector also confirms a positive impact of human capital on R\&D. Other variables that 
were not significant in determining the R\&D intensity are the number of activities, ownership status, age of the firm and multiple firm status. 
Table II: R\&D equations: selection and intensity

\begin{tabular}{|c|c|c|c|c|c|}
\hline Variables & $\begin{array}{l}\text { Probit } \\
(\mathrm{Y} / \mathrm{N})\end{array}$ & $\begin{array}{l}\text { R\&D } \\
\text { per emp. }\end{array}$ & $\begin{array}{l}\text { Probit } \\
(\mathrm{Y} / \mathrm{N})\end{array}$ & $\begin{array}{l}\text { R\&D } \\
\text { per emp. }\end{array}$ & $\begin{array}{l}\text { R\&D } \\
\text { per emp. }\end{array}$ \\
\hline Log(Employment) & $\begin{array}{l}0.342^{* * *} \\
(0.043)\end{array}$ & $\begin{array}{l}-0.900^{* * *} \\
(0.127)\end{array}$ & $\begin{array}{l}0.313^{* * *} \\
(0.047)\end{array}$ & $\begin{array}{l}-0.954^{* * *} \\
(0.138)\end{array}$ & $\begin{array}{l}-0.566^{* * *} \\
(0.142)\end{array}$ \\
\hline Log(Competition) & $\begin{array}{l}-0.278^{* * *} \\
(0.064)\end{array}$ & $\begin{array}{l}0.622^{* * *} \\
(0.174)\end{array}$ & $\begin{array}{l}-0.154 \\
(0.113)\end{array}$ & $\begin{array}{l}0.773^{* * *} \\
(0.252)\end{array}$ & $\begin{array}{l}-0.414^{*} \\
(0.230)\end{array}$ \\
\hline \# Activities & $\begin{array}{l}-0.018 \\
(0.012)\end{array}$ & $\begin{array}{l}-0.023 \\
(0.132)\end{array}$ & $\begin{array}{l}-0.041^{* *} \\
(0.012)\end{array}$ & $\begin{array}{l}-0.083 \\
(0.068)\end{array}$ & $\begin{array}{l}-0.093 \\
(0.062)\end{array}$ \\
\hline Product Y/N & $\begin{array}{l}0.616^{* * *} \\
(0.160)\end{array}$ & $\begin{array}{l}-0.743^{*} \\
(0.434)\end{array}$ & $\begin{array}{l}0.600^{* * *} \\
(0.160)\end{array}$ & $\begin{array}{l}-0.893^{* *} \\
(0.441)\end{array}$ & $\begin{array}{l}0.005 \\
(0.470)\end{array}$ \\
\hline Process Y/N & $\begin{array}{l}0.003 \\
(0.148)\end{array}$ & $\begin{array}{l}0.554 \\
(0.385)\end{array}$ & $\begin{array}{l}0.003 \\
(0.148)\end{array}$ & $\begin{array}{l}0.554 \\
(0.388)\end{array}$ & $\begin{array}{l}0.720^{* *} \\
(0.342)\end{array}$ \\
\hline Org. Y/N & $\begin{array}{l}0.248^{* *} \\
(0.121)\end{array}$ & $\begin{array}{l}-0.204 \\
(0.302)\end{array}$ & $\begin{array}{l}0.258^{* *} \\
(0.120)\end{array}$ & $\begin{array}{l}-0.235 \\
(0.305)\end{array}$ & $\begin{array}{l}-0.109 \\
(0.272)\end{array}$ \\
\hline Skills & $\begin{array}{l}0.147^{* * *} \\
(0.035)\end{array}$ & $\begin{array}{l}0.104 \\
(0.096)\end{array}$ & $\begin{array}{l}0.176^{* * *} \\
(0.054)\end{array}$ & $\begin{array}{l}-0.051 \\
(0.151)\end{array}$ & $\begin{array}{l}0.346^{* *} \\
(0.143)\end{array}$ \\
\hline Group (Y/N) & $\begin{array}{l}0.649^{* * *} \\
(0.105)\end{array}$ & & $\begin{array}{l}0.538^{* * *} \\
(0.104)\end{array}$ & & \\
\hline Foreign & - & $\begin{array}{l}-0.672^{* * *} \\
(0.247)\end{array}$ & - & $\begin{array}{l}-0.697^{* * *} \\
(0.235)\end{array}$ & $\begin{array}{l}-0.093 \\
(0.262)\end{array}$ \\
\hline \# firms & - & $\begin{array}{l}0.007 \\
(0.021)\end{array}$ & - & $\begin{array}{l}0.006 \\
(0.022)\end{array}$ & $\begin{array}{l}-0.019 \\
(0.021)\end{array}$ \\
\hline Log(Age) & $\begin{array}{l}0.005 \\
(0.051)\end{array}$ & $\begin{array}{l}-0.023 \\
(0.132)\end{array}$ & $\begin{array}{l}-0.121 \\
(0.108)\end{array}$ & $\begin{array}{l}-0.015 \\
(0.203)\end{array}$ & $\begin{array}{l}0.067 \\
(0.174)\end{array}$ \\
\hline Intercept & $\begin{array}{l}-11.669^{* * *} \\
(2.315)\end{array}$ & $\begin{array}{l}28.751^{* * *} \\
(6.382)\end{array}$ & $\begin{array}{l}-6.543 \\
(4.354)\end{array}$ & $\begin{array}{l}34.339^{* * *} \\
(9.531)\end{array}$ & $\begin{array}{l}15.429^{*} \\
(8.731)\end{array}$ \\
\hline$\rho_{12} / H_{0}: \rho_{12, t}=0$ & \multicolumn{2}{|c|}{$\begin{array}{l}0.999^{* * *} \\
(0.046)\end{array}$} & \multicolumn{2}{|c|}{$\begin{array}{l}0.943^{* * *} \\
(0.016)\end{array}$} & $\begin{array}{c}0.957^{* * *} \\
(0.234)\end{array}$ \\
\hline Log-likelihood & \multirow{5}{*}{\multicolumn{2}{|c|}{$\begin{array}{c}-1308.468 \\
\text { Tobit II } \\
734 \\
502 / 232 \\
\text { no } \\
\end{array}$}} & \multirow{5}{*}{\multicolumn{2}{|c|}{$\begin{array}{l}-1397.267 \\
\text { Tobit II } \\
734 \\
502 / 232 \\
\text { Yes, } \xi_{\mathrm{i}}=\mathbf{0}\end{array}$}} & -1307.916 \\
\hline Est. method & & & & & Min. Dist. \\
\hline \# obs. & & & & & 734 \\
\hline Censored/Uncens. & & & & & $502 / 232$ \\
\hline Random effects & & & & & Yes, full \\
\hline
\end{tabular}

Note: ML-estimates with (robust) standard errors in parentheses. Statistical significance is indicated by stars: *: $10 \%$, ${ }^{* *}: 5 \%,{ }^{* *}: 1 \%$ significance level). Reported is the change in probability that R\&D is positive for a unit change in each of the variables.

The results of the most general model determining R\&D propensities (model 3) suggest that larger firms are significantly more likely to engage in R\&D. Moreover engagement in product innovation, as well as engagement in organizational innovation and more human capital, increases the likelihood that food firms undertake R\&D. Our model does suggest a varying impact of product, process and organization innovation on the decision versus the level of R\&D outcomes: process innovation seems to play an important role in explaining the R\&D level, while organization and product innovation affect the probability to engage in R\&D. Two additional variables that were significant in determining the probability of R\&D are the positive effect of group membership and the negative impact of diversification ("number of activities").

Comparing the estimation results of the third and the fifth column with the remaining columns reveal that accounting for the full unobserved heterogeneity seem to affect the estimation results. The results show that when the full heterogeneity is taken into account, the product innovation, skills and the foreign ownership controls lose their effects. Notice also that 
the correlation term rho is significant in both the selection and level equation, pointing out the necessity of estimating a selection model for the unobserved intensity.

\subsection{The patent equation}

Next we consider the estimates of the patent equation discussed in subsection 4.2. The likelihood ratio test comparing the Poisson model with the Negative Binomial model reveals that the overdispersion parameter, denoted by $\alpha$, equals zero (i.e., $H_{0}: \alpha=0$ ) is conclusively rejected. Three models have been estimated using the pooled sample. The first model only includes (the logs) of R\&D per employee and firm size estimated by ML, model II is a full model without the additional random effects while model III includes the entire unobserved heterogeneity.

Table III: Patent equations: two-part Hurdle model

\begin{tabular}{|c|c|c|c|c|c|c|}
\hline Variables & $\begin{array}{l}\text { I } \\
\text { Logit } \\
(\mathrm{Y} / \mathrm{N}) \\
\end{array}$ & Patents & $\begin{array}{c}\text { II } \\
\text { Logit } \\
(\mathrm{Y} / \mathrm{N}) \\
\end{array}$ & Patents & $\begin{array}{l}\text { III } \\
\text { Logit } \\
(\mathrm{Y} / \mathrm{N}) \\
\end{array}$ & Patents \\
\hline Log(R\&D per emp.) & $\begin{array}{l}0.303^{* * *} \\
(0.102)\end{array}$ & $\begin{array}{l}0.080^{*} \\
(0.047)\end{array}$ & $\begin{array}{l}0.369^{* * *} \\
(0.107)\end{array}$ & $\begin{array}{l}0.096^{* *} \\
(0.042)\end{array}$ & $\begin{array}{l}0.325^{* * *} \\
(0.109)\end{array}$ & $\begin{array}{l}0.035 \\
(0.039)\end{array}$ \\
\hline Log(Employments) & $\begin{array}{l}1.096^{* * *} \\
(0.179)\end{array}$ & $\begin{array}{l}0.574^{* * *} \\
(0.105)\end{array}$ & $\begin{array}{l}0.755^{* * *} \\
(0.196)\end{array}$ & $\begin{array}{l}0.362^{* * *} \\
(0.117)\end{array}$ & $\begin{array}{l}0.825^{* * *} \\
(0.197)\end{array}$ & $\begin{array}{l}0.554^{* * *} \\
(0.156)\end{array}$ \\
\hline \# Activities & & & $\begin{array}{l}-0.117 \\
(0.082) \\
\end{array}$ & $\begin{array}{l}0.000 \\
(0.047) \\
\end{array}$ & $\begin{array}{l}0.021 \\
(0.065) \\
\end{array}$ & $\begin{array}{l}0.072 \\
(0.057) \\
\end{array}$ \\
\hline Log(Competition) & & & $\begin{array}{l}0.200^{* * *} \\
(0.076)\end{array}$ & $\begin{array}{l}0.059^{* *} \\
(0.031)\end{array}$ & $\begin{array}{l}0.192^{* *} \\
(0.072)\end{array}$ & $\begin{array}{l}-0.005 \\
(0.034)\end{array}$ \\
\hline Product Y/N & & & $\begin{array}{l}0.638 \\
(0.749)\end{array}$ & $\begin{array}{l}-0.232 \\
(0.519)\end{array}$ & $\begin{array}{l}0.479 \\
(0.744)\end{array}$ & $\begin{array}{l}-1.556^{* *} \\
(0.669)\end{array}$ \\
\hline Process Y/N & & & $\begin{array}{l}-0.396 \\
(0.736) \\
\end{array}$ & $\begin{array}{l}0.168 \\
(0.442) \\
\end{array}$ & $\begin{array}{l}-0.407 \\
(0.720) \\
\end{array}$ & $\begin{array}{l}1.341^{* *} \\
(0.624)\end{array}$ \\
\hline Org. Y/N & & & $\begin{array}{l}0.280 \\
(0.517)\end{array}$ & $\begin{array}{l}0.116 \\
(0.313)\end{array}$ & $\begin{array}{l}-0.120 \\
(0.518)\end{array}$ & $\begin{array}{l}0.208 \\
(0.347)\end{array}$ \\
\hline Skills & & & $\begin{array}{l}0.539^{* * *} \\
(0.183)\end{array}$ & $\begin{array}{l}0.335^{* * *} \\
(0.118)\end{array}$ & $\begin{array}{l}0.412^{* *} \\
(0.183)\end{array}$ & $\begin{array}{l}-0.061 \\
(0.109)\end{array}$ \\
\hline Group (Y/N) & & & $\begin{array}{l}1.972^{* * *} \\
(0.707)\end{array}$ & $\begin{array}{l}1.337^{* *} \\
(0.581)\end{array}$ & $\begin{array}{l}1.743^{* * *} \\
(0.704)\end{array}$ & $\begin{array}{l}0.409 \\
(0.684)\end{array}$ \\
\hline Log(Age) & & & $\begin{array}{l}0.471 \\
(0.389)\end{array}$ & $\begin{array}{l}0.354 \\
(0.265)\end{array}$ & $\begin{array}{l}0.214 \\
(0.179)\end{array}$ & $\begin{array}{l}0.118 \\
(0.518)\end{array}$ \\
\hline Intercept & $\begin{array}{l}-9.874^{* * *} \\
(1.144)\end{array}$ & $\begin{array}{l}-4.223^{* * *} \\
(0.891)\end{array}$ & $\begin{array}{l}-6.100^{*} \\
(3.712)\end{array}$ & $\begin{array}{l}-5.200^{* *} \\
(2.195)\end{array}$ & $\begin{array}{l}-2.361 \\
(3.353)\end{array}$ & $\begin{array}{l}-2.722 \\
(3.399)\end{array}$ \\
\hline$\alpha$ & \multicolumn{2}{|c|}{$0.233^{* * *}$} & \multicolumn{2}{|c|}{$0.419^{* * *}$} & \multicolumn{2}{|c|}{$0.199^{* * * *}$} \\
\hline $\begin{array}{l}\sigma_{\varepsilon}^{2} \\
\sigma_{z}^{2} \\
\rho \sigma_{\varepsilon}^{2} \sigma_{\varepsilon}^{2}\end{array}$ & & & & & \multicolumn{2}{|c|}{$\begin{array}{l}3.445^{* * *} \\
3.610^{* * *} \\
2.960^{* *}\end{array}$} \\
\hline Log-likelihood & \multirow{2}{*}{\multicolumn{2}{|c|}{$\begin{array}{c}-686.331 \\
734\end{array}$}} & \multirow{2}{*}{\multicolumn{2}{|c|}{$\begin{array}{c}-636.737 \\
729\end{array}$}} & \multirow{2}{*}{\multicolumn{2}{|c|}{$\begin{array}{c}-789.412 \\
729\end{array}$}} \\
\hline \# obs. & & & & & & \\
\hline
\end{tabular}

Note: Note: ML-estimates with (robust) standard errors in parentheses. Statistical significance is indicated by stars: *: $10 \%,{ }^{* *}: 5 \%,{ }^{* *}: 1 \%$ significance level). Reported in the logit equation is the change in probability (that patenting is positive) for a unit change in each of the explanatory variables.

Turning to the contribution of R\&D spending per employee on patent counts in the food industry, we find a positive and significant effect on both the number of patents and the probability part of the model. We see that including the random effects, capturing the unobserved ability to be innovative, results in an improvement of the log-likelihood values; however, the coefficients on R\&D and some of the other explanatory variables are affected by 
this inclusion. Turning to the significant effects, the coefficients of the log of employment are always positive, indicating that both the likelihood and the number of patents are increasing with firm size. When we turn to the full model, competition does seem to play a significant role on the probability to patent, while this effect is not significant on patent applications. When turning to the other firm-level innovation factors influencing patent behavior, firms which are engaged in product innovation apply for a lower number of patents while a firm's involvement with process innovation yields a higher number of patents. These innovation characteristics do not have any impact on the probability to apply for at least one patent. We also find a strong presence of random effects, and the correlation between these random effects is ascertained at a one percent significance.

We explore the sensitivity of our results using an alternative distribution, where we employ a zero-inflated count model instead of a two part Hurdle model. Table IV provides the estimates of the patent equation using zero-inflated models for zero inflated Poisson (ZIP, model IV) and the zero inflated negative binomial (ZINB, model V) models. In each case, the same regressors enter the logit model for zero inflation and the count model. We note that the likelihood ratio test (not reported) comparing the ZINB model with the ZIP model favors the latter. Although, in the presence of unobserved heterogeneity and overdispersion, the ZINB model is inconsistent if overdispersion is wrongly specified (Staub and Winkelmann, 2013).

Table IV: Patent equations: Zero-inflated model

\begin{tabular}{|c|c|c|c|c|}
\hline Variables & $\begin{array}{l}\text { IV } \\
\text { ZI } \\
\text { Logit }\end{array}$ & $\begin{array}{l}\text { Patents } \\
\text { NB }\end{array}$ & $\begin{array}{l}\quad \mathrm{V} \\
\text { ZI } \\
\text { Logit }\end{array}$ & $\begin{array}{l}\text { Patents } \\
\text { Poisson }\end{array}$ \\
\hline Log(R\&D per emp.) & $\begin{array}{l}-0.513 \\
(0.787)\end{array}$ & $\begin{array}{l}0.330^{* *} \\
(0.094)\end{array}$ & $\begin{array}{l}-0.103 \\
(0.092)\end{array}$ & $\begin{array}{l}0.089^{* *} \\
(0.040)\end{array}$ \\
\hline Log(Employments) & $\begin{array}{l}-0.814^{* * *} \\
(0.211)\end{array}$ & $\begin{array}{l}1.055^{* * *} \\
(0.295)\end{array}$ & $\begin{array}{l}-0.717^{* *} \\
(0.324)\end{array}$ & $\begin{array}{l}0.588^{* * *} \\
(0.263)\end{array}$ \\
\hline \# Activities & $\begin{array}{l}-0.800^{*} \\
(0.321)\end{array}$ & $\begin{array}{l}0.028 \\
(0.139)\end{array}$ & $\begin{array}{l}0.114^{*} \\
(0.059)\end{array}$ & $\begin{array}{l}0.292^{* * *} \\
(0.063)\end{array}$ \\
\hline Log(Competition) & $\begin{array}{l}0.827 \\
(0.452)\end{array}$ & $\begin{array}{l}0.265^{* * *} \\
(0.076)\end{array}$ & $\begin{array}{l}-0.136^{*} \\
(0.078)\end{array}$ & $\begin{array}{l}-0.059 \\
(0.042)\end{array}$ \\
\hline Product Y/N & $\begin{array}{l}-3.266 \\
(3.112)\end{array}$ & $\begin{array}{l}-0.519 \\
(0.752)\end{array}$ & $\begin{array}{l}-2.748 \\
(2.323)\end{array}$ & $\begin{array}{l}-1.678^{*} \\
(0.882)\end{array}$ \\
\hline Process $\mathrm{Y} / \mathrm{N}$ & $\begin{array}{l}6.642 \\
(7.112) \\
\end{array}$ & $\begin{array}{l}0.900^{* *} \\
(0.389)\end{array}$ & $\begin{array}{l}2.073 \\
(2.255) \\
\end{array}$ & $\begin{array}{l}0.896^{* *} \\
(0.386) \\
\end{array}$ \\
\hline Org. Y/N & $\begin{array}{l}-2.859 \\
(3.521)\end{array}$ & $\begin{array}{l}-0.431 \\
(0.472)\end{array}$ & $\begin{array}{l}-0.007 \\
(0.638)\end{array}$ & $\begin{array}{l}0.494 \\
(0.602)\end{array}$ \\
\hline Skills & $\begin{array}{l}2.610 \\
(3.092)\end{array}$ & $\begin{array}{l}0.689^{* * *} \\
(0.117)\end{array}$ & $\begin{array}{l}0.409 \\
(0.431)\end{array}$ & $\begin{array}{l}1.255^{* * *} \\
(0.254)\end{array}$ \\
\hline Group $(\mathrm{Y} / \mathrm{N})$ & $\begin{array}{l}-6.684 \\
(8.667)\end{array}$ & $\begin{array}{l}1.261^{*} \\
(0.751)\end{array}$ & $\begin{array}{l}-1.921^{* *} \\
(0.961)\end{array}$ & $\begin{array}{l}0.623 \\
(1.208)\end{array}$ \\
\hline $\log ($ Age $)$ & $\begin{array}{l}0.461 \\
(0.644)\end{array}$ & $\begin{array}{l}0.097 \\
(0.252)\end{array}$ & $\begin{array}{l}0.362 \\
(0.359)\end{array}$ & $\begin{array}{l}0.470 \\
(0.415)\end{array}$ \\
\hline Intercept & $\begin{array}{l}-1.207 \\
(2.752)\end{array}$ & $\begin{array}{l}-2.873 \\
(2.836)\end{array}$ & $\begin{array}{l}-1.582 \\
(4.941)\end{array}$ & $\begin{array}{l}-12.695^{* * *} \\
(4.667)\end{array}$ \\
\hline$\alpha$ & \multicolumn{4}{|c|}{$0.221^{* * *}$} \\
\hline $\begin{array}{l}\sigma_{\varepsilon}^{2} \\
\sigma_{\varepsilon}^{2} \\
\rho \sigma_{s}^{2} \sigma_{\varepsilon}^{2}\end{array}$ & \multicolumn{2}{|c|}{$\begin{array}{l}2.818^{* * *} \\
3.147^{* * *} \\
2.455^{* * *}\end{array}$} & \multicolumn{2}{|c|}{$\begin{array}{l}2.475^{* * *} \\
3.001^{* *} \\
2.547^{* * *}\end{array}$} \\
\hline Log-likelihood & \multirow{2}{*}{\multicolumn{2}{|c|}{$\begin{array}{c}-636.737 \\
729 \\
\end{array}$}} & \multirow{2}{*}{\multicolumn{2}{|c|}{$\begin{array}{c}-689.412 \\
729 \\
\end{array}$}} \\
\hline \# obs. & & & & \\
\hline
\end{tabular}

Note: ML-estimates with (robust) standard errors in parentheses. Statistical significance is indicated by stars: *: $10 \%,{ }^{* *}: 5 \%,{ }^{* *}: 1 \%$ significance level). 
Generally, we find that the parameter estimates are quite similar between the ZINB and ZIP estimator, although there are some exceptions. We first discuss the estimation results for patent count model. Later we discuss the results corresponding to the zero inflation probability equation. As expected, the one year lagged R\&D per employee (which is the corresponding semielasticity of the number of patents with respect to lagged R\&D), again taken at its predicted values from the Tobit II specification, and the elasticity of size ("employment") have a significant and positive impact on the number of patent applications. The "skills" turn out to have a significant positive effect on patent applications confirming our hypothesis that human capital skills and output innovation are positively correlated. The dummy variable "process" innovation is also positively associated with patent applications, while "product" innovation has a significant and negative impact according to the Poisson specification. In case of the other variables, the ZINB model detects a positive effect of "competition" and the "group" variable, but no so in the ZIP model while an opposite relationship is found for the "number of activities" suggesting some caution in interpreting these effects.

Next, we discuss the estimation results corresponding to the part of the zero inflation probability. Under both the ZIP and the ZINB specification, the results suggest that a unit increase in size decreases the probability of an inflated zero patent by around 0.80 . In case of the "number of activities", this has a positive and significant effect on the probability of an extra zero patent under both specifications. Only from the Poisson specification, the group variable. as well as competition have a negative effect on the zero inflation probability. When comparing the results on patents with the ZIP and ZINB specification, we see relatively minor changes of the log-likelihood values.

Under the maintained assumption of two part Hurdle or zero-inflated data generating process, we can also calculate the total marginal effects of those variables, which appear in both the logit and the count part of either the Hurdle or the zero-inflated models. ${ }^{11}$ In setting the $\left(1-p_{i t}\right)$ probability mass to its overall mean value, the total estimated effects of each of the most important determinants according to the various models specifications (model III-V) are summarized in Table $\mathrm{V}$ below,

Table V: Total estimated effects of patent determinants

\begin{tabular}{|l|l|l|l|}
\hline Log(R\&D per emp.) & $0.167^{* *}$ & $0.638^{*}$ & $0.151^{* *}$ \\
& $(0.091)$ & $(0.375)$ & $(0.070)$ \\
\hline $\log ($ Employment) & $0.996^{* *}$ & $1.562^{* *}$ & $1.018^{* * *}$ \\
& $(0.314)$ & $(0.615)$ & $(0.237)$ \\
\hline \# activities & 0.081 & $0.471^{*}$ & $0.223^{* * *}$ \\
& $(0.061)$ & $(0.285)$ & $(0.064)$ \\
\hline Log(Competition) & $0.104^{*}$ & $0.676^{* *}$ & 0.022 \\
& $(0.061)$ & $(0.269)$ & $(0.036)$ \\
\hline Product Y/N & $-1.221^{*}$ & 0.968 & -0.029 \\
& $(0.711)$ & $(0.957)$ & $(1.115)$ \\
\hline Process Y/N & $1.421^{*}$ & -0.291 & -0.347 \\
& $(0.818)$ & $(0.957)$ & $(1.223)$ \\
\hline Skills & $1.362^{* *}$ & $1.043^{* *}$ & $1.009^{* * *}$ \\
& $(0.571)$ & $(0.528)$ & $(0.186)$ \\
\hline Group (Y/N) & -1.214 & 5.272 & $1.779^{* *}$ \\
& $(1.404)$ & $(5.045)$ & $(0.870)$ \\
\hline
\end{tabular}

\footnotetext{
${ }^{11}$ As shown by Cameron and Trivedi (2013), the total marginal effects of any variable appearing in both $\lambda_{i t}$ and $p_{i t}$ in respectively equation (6) and (9) is equal to sum of the corresponding component of $\delta_{3}$ and $\delta_{4}$, where the latter has to be multiplied by $1-p_{i t}$.
} 
Note: Total marginal effects calculated from the zero inflation and the count part of the zero inflation model; on the basis of the overall mean of $1-p_{\text {it }}$.(see footnote 11 )

Altogether, we observe the following. Consistent with the related work in the literature (e.g., Hall, 2011) our analysis based on the total estimated effects strongly suggests that patenting is associated with R\&D intensities, even after controlling for other forms of firm-level innovation characteristics suggesting that the amount of patenting is not exclusively dependent on R\&D. In the food processing sector studied here, Gopinath and Vasada (1999) for a panel of US firms and Alarcon and Polonio (2014) for a panel of Spanish firms, also found a positive effect. Both size and to lesser extent the firm's scope of activities are positively associated with patenting. The larger the firm and the larger the number of food sub-sectors wherein firms are involved, the greater the technological opportunities. As discussed in section 4.3. with specific reference to the food industry, our results corroborate with a majority of other studies that have also confirmed that size is a strong determinant to explain innovation. An overall competition effect is also partially confirmed by the data; however, we note that these significant effects can be driven by either the positive effects on probability to patenting or on the amount of patenting.

To the extent that R\&D may be considered as one of the most important determinants in explaining patent propensities, our evidence suggests that there is no clear robust total effect of the firms' past and current introduction of new products and process innovation on patent stocks. Roper and Hewitt-Dundas (2008) and Farber and Hensen (2004) examining the relationship between patents granted and sales of innovative products using manufacturing data for a group of major European countries did not find a significant relationship neither. The lack of any clear statistically robust effect could be explained by a number of factors. According to Mansfield (1986) and Hall (2011), very few additional inventions were commercially introduced because of patent protection. Faber and Hensen (2004) note that rather the economic infrastructure conditions shape the patent innovation activities. Less surprising is the strong positive relationship between patent stock counts (rather than its probabilities) and the engagement in past and current process innovation. As discussed previously, technical innovation has played a prominent role in launching new products, which is considered as a characteristics of this industry. We may also infer that a positive relationship between process innovation and patenting (merely as patent counts) may be explained by a technological complementarity effect whereby secrecy and/or technical disclosure may be less of an issue.

Our results are also consistent with the view that high wage firms, as a proxy to a capture high quality and/or skilled workforce, is associated with more patenting. An important implication from this result is that this added explanatory dimension of innovation is significant and contributes in explaining one of the most important aspects of a firm's patenting behavior. The high positive coefficients clearly indicate that higher skills especially influence the amount of patenting. Indeed, this results helps us also to understand and to categorize the jointly impact of other forms of output innovation.

\subsection{Some additional robustness checks}

A few caveats should be born in mind while interpreting the above results. First, it is reasonable to expect that not only the number of patent applications but also the "quality" of the patents can be explained by our determinants. In order to test this, we adopt the same specification as in equations (6-8), where the dependent variable is measured as the total number of forward citations per patent, which is the number of times the patent is cited in other patents later. A large number of forward citations means that the patent builds upon subsequent innovations. It also means that such patents tend to yield more profits for the firm holding the patent (Nagaoka et al., 2010). The analysis is conducted to patents with forward citations of the most recent patents (December, 2015). The results are presented in Table 6 below. 
Table VI: Patent citation equations: Two-part Hurdle model

\begin{tabular}{|c|c|c|c|c|c|c|}
\hline Variables & $\begin{array}{c}\quad \text { III' } \\
\text { Logit } \\
(\mathrm{Y} / \mathrm{N}) \\
\end{array}$ & Patents & $\begin{array}{l}\text { IV' } \\
\text { ZI } \\
\text { Logit }\end{array}$ & $\begin{array}{l}\text { Patents } \\
\text { NB }\end{array}$ & $\begin{array}{l}V^{\prime} \\
\text { ZI } \\
\text { Logit } \\
\end{array}$ & $\begin{array}{l}\text { Patents } \\
\text { Poisson } \\
\end{array}$ \\
\hline Log(R\&D per emp.) & $\begin{array}{l}0.500^{* * *} \\
(0.008)\end{array}$ & $\begin{array}{l}0.035 \\
(0.039)\end{array}$ & $\begin{array}{l}0.337 \\
(0.272)\end{array}$ & $\begin{array}{l}0.482^{* * *} \\
(0.089)\end{array}$ & $\begin{array}{l}0.021 \\
(0.153)\end{array}$ & \begin{tabular}{|l|}
$0.571^{* *}$ \\
$(0.238)$
\end{tabular} \\
\hline Log(Employments) & $\begin{array}{l}0.976^{* *} \\
(0.406)\end{array}$ & $\begin{array}{l}1.028^{* *} \\
(0.479)\end{array}$ & $\begin{array}{l}0.033 \\
(0.058)\end{array}$ & $\begin{array}{l}0.534^{* *} \\
(0.243)\end{array}$ & $\begin{array}{l}-0.025 \\
(0.387)\end{array}$ & $\begin{array}{l}0.741^{* *} \\
(0.325)\end{array}$ \\
\hline \# Activities & $\begin{array}{l}0.087^{* *} \\
(0.039)\end{array}$ & $\begin{array}{l}0.082 \\
(0.047) \\
\end{array}$ & $\begin{array}{l}-0.333^{* *} \\
(0.148) \\
\end{array}$ & $\begin{array}{l}0.144 \\
(0.094) \\
\end{array}$ & $\begin{array}{l}-0.260 \\
(0.158)\end{array}$ & $\begin{array}{l}0.149^{* *} \\
(0.070) \\
\end{array}$ \\
\hline Log(Competition) & $\begin{array}{l}-0.101 \\
(0.114) \\
\end{array}$ & $\begin{array}{l}0.164 \\
(0.172) \\
\end{array}$ & $\begin{array}{l}-0.045 \\
(0.747) \\
\end{array}$ & $\begin{array}{l}-0.319 \\
(0.419) \\
\end{array}$ & $\begin{array}{l}-0.117 \\
(0.253) \\
\end{array}$ & \begin{tabular}{|c|}
$-0.307^{* *}$ \\
$(0.136)$ \\
\end{tabular} \\
\hline Product Y/N & $\begin{array}{l}0.497 \\
(0.459) \\
\end{array}$ & $\begin{array}{l}0.409^{*} \\
(0.249) \\
\end{array}$ & $\begin{array}{l}-4.055 \\
(6.551) \\
\end{array}$ & $\begin{array}{l}2.687^{*} \\
(1.610)\end{array}$ & $\begin{array}{l}3.341^{* *} \\
(1.395)\end{array}$ & $\begin{array}{l}3.748^{* *} \\
(1.674) \\
\end{array}$ \\
\hline Process Y/N & $\begin{array}{l}0.549 \\
(0.742)\end{array}$ & $\begin{array}{l}0.829 \\
(0.794)\end{array}$ & $\begin{array}{l}5.568 \\
(4.916)\end{array}$ & $\begin{array}{l}3.797^{* * *} \\
(1.021)\end{array}$ & $\begin{array}{l}1.917^{* *} \\
(0.852)\end{array}$ & $\begin{array}{l}2.271 \\
(1.397) \\
\end{array}$ \\
\hline Org. Y/N & $\begin{array}{l}0.219 \\
(0.529) \\
\end{array}$ & $\begin{array}{l}0.196 \\
(0.356) \\
\end{array}$ & $\begin{array}{l}0.246 \\
(1.301) \\
\end{array}$ & $\begin{array}{l}-0.284 \\
(0.742) \\
\end{array}$ & $\begin{array}{l}-0.557 \\
(0.754) \\
\end{array}$ & \begin{tabular}{|l|}
-0.851 \\
$(0.623)$ \\
\end{tabular} \\
\hline Skills & $\begin{array}{l}0.408^{* *} \\
(0.200)\end{array}$ & $\begin{array}{l}0.639 \\
(0.459)\end{array}$ & $\begin{array}{l}-1.312 \\
(0.549)\end{array}$ & $\begin{array}{l}-0.269 \\
(0.481)\end{array}$ & $\begin{array}{l}-0.507^{*} \\
(0.304)\end{array}$ & \begin{tabular}{|l|}
0.242 \\
$(0.233)$
\end{tabular} \\
\hline Group $(\mathrm{Y} / \mathrm{N})$ & $\begin{array}{l}0.981^{* *} \\
(0.247)\end{array}$ & $\begin{array}{l}0.784 \\
(0.987)\end{array}$ & $\begin{array}{l}-5.967^{* * *} \\
(1.748)\end{array}$ & $\begin{array}{l}0.986 \\
(0.755)\end{array}$ & $\begin{array}{l}-2.016^{* *} \\
(1.021)\end{array}$ & \begin{tabular}{|l}
-0.864 \\
$(0.627)$ \\
\end{tabular} \\
\hline Log(Age) & $\begin{array}{l}0.214 \\
(0.179) \\
\end{array}$ & $\begin{array}{l}-0.084 \\
(0.758) \\
\end{array}$ & $\begin{array}{l}1.038 \\
(1.144)\end{array}$ & $\begin{array}{l}-0.649 \\
(0.762) \\
\end{array}$ & $\begin{array}{l}1.196^{*} \\
(0.692) \\
\end{array}$ & \begin{tabular}{|l|}
-0.062 \\
$(0.260)$ \\
\end{tabular} \\
\hline Intercept & $\begin{array}{l}-5.003^{* *} \\
(3.353)\end{array}$ & $\begin{array}{l}-3.753^{* *} \\
(1.541)\end{array}$ & $\begin{array}{l}5.601 \\
(3.522) \\
\end{array}$ & $\begin{array}{l}-1.769 \\
(1.115) \\
\end{array}$ & $\begin{array}{l}11.173^{* * *} \\
(2.251)\end{array}$ & \begin{tabular}{|l}
$-6.007^{* * *}$ \\
$(2.187)$ \\
\end{tabular} \\
\hline$\alpha$ & \multirow{2}{*}{\multicolumn{2}{|c|}{$\begin{array}{c}0.506^{* *} \\
0.107 \\
1.006^{* * *}\end{array}$}} & \multicolumn{2}{|c|}{$0.707^{*}$} & \\
\hline $\begin{array}{l}\sigma_{\varepsilon}^{2} \\
\sigma_{\varepsilon}^{2} \\
\rho \sigma_{\varepsilon}^{2} \sigma_{\varepsilon}^{2}\end{array}$ & & & & $\begin{array}{l}0^{* * *} \\
1^{* * *} \\
4^{* * *}\end{array}$ & & $\begin{array}{l}3^{* * *} \\
2^{* * *} \\
6^{* * *}\end{array}$ \\
\hline Log-likelihood & \multirow{2}{*}{\multicolumn{2}{|c|}{$\begin{array}{c}-333.930 \\
729\end{array}$}} & \multirow{2}{*}{\multicolumn{2}{|c|}{$\begin{array}{c}-219.749 \\
729\end{array}$}} & & .268 \\
\hline \# obs. & & & & & & \\
\hline
\end{tabular}

Note: ML-estimates with (robust) standard errors in parentheses. Statistical significance is indicated by stars: *: $10 \%$, **: $5 \%, * * *: 1 \%$ significance level). Reported in the logit equation is the change in probability (that patenting is positive) for a unit change in each of the explanatory variables.

When patent citations are used as an indicator for the technological importance of the patent, our results show that the coefficient on the effect of product innovation becomes much more important in determining the citations probability, as well as the number of citations, while we found in the previous analysis a negative and significant coefficient on the actual number of patents. The impact of process innovation is negligible. Furthermore, the effect of the R\&D coefficient does not have any effect on the probability that a patent will be forwarded cited. Another interesting finding is that the results in terms of the effect of skills on patent citations becomes very weak or insignificant.

As another robustness check, we analyzed the dynamics of the model, that is, considering the time lags in the innovation determinants and the effect of lagged patent counts on current patent counts while addressing unobserved heterogeneity. Regarding the choice on time lags, we tested for the best fitting lags, and we obtained more significant results, using the Bayes Information Criteria, with lagged $R \& D$ up to one year and the variables for product/process/organization innovation expressed as a 1/0 dummy variable taking the value 1 if the firm has been in current 
or prior years engaged in of the innovation activities. Note that one of the particularities of the innovation dummies is that, for each period, innovation incidence pertains to any of the threeyear period. We also considered the specification by the current period dummy but did not affect our key results. Regarding the specification by including the lagged patent behavior, we considered two specifications: expressed as a dummy variable and another specification by including lagged patent counts. However, because of convergence problems, we did not obtain satisfactory results. Therefore as a final robustness check we also re-estimated the patent equation in dynamic form using the system GMM, which includes fixed effects and tackles endogeneity of the right-hand-side variables by using their lagged values (in first differences and levels) as instruments. Therefore, under the assumption that current random shocks are uncorrelated with past values from firm-level regressors, we use past values from t-2 onwards as instruments and $t-1$ periods for the innovation dummies. Using the full specification, the effect of persistence in the log number of patents and citations is now confirmed. The persistence in patent counts has an elasticity of 0.20 , while the effects of the log of R\&D per employee remain fairly robust with an elasticity of 0.03 . The effect of the other variables are very similar to the ones presented in Table 3 and 4; however, the effect of output innovation on patents becomes insignificant. We note that the test for the validity of the instruments using the Sargan test yields the problem of weak instruments, and we note that the estimates obtained are sensitive to the instruments used.

\section{Conclusion}

In this paper, we have estimated several alternatives of count models for panel data, with the main purpose of analyzing a firm's patent output in the food processing industry, using firmlevel data for the period 2000-2008. Empirical evidence indicates that patent output increases with R\&D intensities and skills, after controlling for other innovation output measures, other firm-level characteristics and unobserved heterogeneity. The importance of unobserved heterogeneity, which captures managerial know-how, other forms of ability or other timeinvariant characteristics, is confirmed. In this sense, the availability of these other innovative determinants enables us to better assess in which way $R \& D$ and skills translate into higher patent activities. In addition, we are also in a better position to assess the true determinants of patenting.

The results are in line with a robust finding inferred by food innovation studies. First, we find that process innovation has a major impact on patent counts. Second, our results are also consistent with the view that high wage firms, as a proxy to capture high quality and/or skilled workforce, is associated with more patenting. Third, the results suggest that the time-invariant unobserved firm-level characteristics are deemed to be very important for determining R\&D and patenting. The inclusion of unobserved heterogeneity affect especially the other innovation determinants. Fourth, when we control for the quality of patenting, product becomes an important determinant in explaining the patent counts, and the effect of process innovation becomes insignificant. Finally, we also find that dynamics are import by including the lagged number of patent counts, however, the significance of product and process innovation vanishes, while the other determinants remain unaffected.

Our results have some direct policy relevance. Over the past decade, policy makers have regarded the transformation towards a knowledge-based economy, a key priority towards higher growth performance. Consequently, policy makers have laid out numerous incentives in enhancing innovation activities. From the firm-size perspective, our results reveal that small firms tend to be the smallest innovators measured by their R\&D reporting frequencies, their R\&D levels, and the number of patents issues. However, our results indicate that especially smaller firms yield higher innovation intensities. From the perspective of designing policies with the aim to increase innovation, not only the size effect is important as our results reveal heterogeneous drivers of innovation in terms of human capabilities, firm-intrinsic R\&D and 
output-related innovation activities as well as other unobserved firm-level heterogeneity. More research should be oriented towards analyzing this type of variable impacts.

\section{References}

Acosta M., Coronado D., Dolores Leon M., Martinez M. 2009. Production of university technological knowledge in European regions: Evidence from patent data. Regional Studies 43, 1167-1181.

Adams J., Chiang D., Jensen J. 2003. The influence of Federal laboratory R\&D on industrial research. Review of Economics and Statistics 85, 1003-1020.

Alfranca O., Rama R., von Tuzelmann N. 2002. A patent analysis of global food and beverage firms: The persistence of innovation. Agribusiness 18, 349-368.

Alfranca O., Rama R., von Tuzelmann N. 2004. Innovation spells in the multinational agri-food sector. Technovation 24, 599-614.

Alarcon S., Polonio L. 2014. Patents, research \& development and technological cooperation in the Spanish agri-food industry. New Medit 3, 23-29.

Aghion Ph., Bloom N., Blundell R., Griffith R., Howitt P. 2005. Competition and Innovation: An Inverted-U Relationship. The Quarterly Journal of Economic 120, 701-728.

Amemiya T. 1985. Advanced Econometrics. Harvard University Press.

Arundel A., Kabla I. 1998. What percentage of innovations are patented? Empirical estimates for European firms. Research Policy 27, 127-141.

Avermaete T., Viaene J., Morgan E., Pitts E., Crawford N. and Mahon D. 2004. Determinants of product and process innovation in small food manufacturing firms. Trends in Food Science \& Technology 15, 474-483.

Balasubramanian N., Sivadasan J. 2011. What Happens When Firms Patent? New Evidence from U.S. Economic Census Data. The Review of Economics and Statistics 93, 126-146.

Bloom N., Van Reenen J. 2002. Patents, Real Options and Firm Performance. The Economic Journal 112, 97--116.

Bound, J., Cummins C., Grilliches Z., Hall B., Jaffe A. 1984. Who does R\&D and Who does Patents?, in Z. Grilliches (ed.), R\&D, Patents and Productivity, University of Chicago, Press for the National Bureau of Economic Research, Chicago.

Brewin D., Monchuk D., Partridge M.D. 2009. Examining the adoption of product and process innovations in the Canadian food processing. Canadian Journal of Agricultural Economics 57, 1744-7976.

Brouwer E., Kleinknecht A. 1999. Innovative Output, and a Firm's Propensity to Patent: An Exploration of CIS Micro Data. Research Policy 28, pp. 615--24. 
Batterink M., Wubben E., Omta S. 2006. Factors related to innovative output in the Dutch agrifood industry. Journal on Chain and Network Science 6, 31-44.

Cameron C, Trivedi P. 2013. Regression Analysis of Count Data. 2nd edition, Cambridge University Press.

Confederation of Food and Drink Industries Europe (CIAA). 2010. Supporting the competitiveness of the European food and drink industry. CIAA Competitiveness Report 2010.

Centraal Bureau voor de Statistiek (CBS). 2010. Patentsaanvragers en - aanvragen uit Nederland: Eerste koppelingen van patentregistraties met het Algemeen Bedrijvenregister.

Correa, J.A. 2012. Innovation and competition: an unstable relationship. Journal of Applied Econometrics 27, 160-166.

Demsetz, H. 1969. Information and Efficiency: Another Viewpoint. Journal of Law and Economics $12,1--22$,

Dobbelaere S., Vancauteren M. 2014. Market imperfections, skills and TFP: Firm-level evidence on Belgium and the Netherlands. NBB Working Paper 268, Paper prepared for the NBB colloquium on Total Factor Productivity: measurement, determinants and effects.

Dobson P., Chakraborty W. 2009. Private Labels and Branded Goods: Consumers Horrors and Heroes. In: Private Labels, Brands and Competition Policy: The Changing Landscape of Retail Competition. A.Ezrachi and Ulf Bernitz (eds.). Oxford University Press.

Dustmann C., Rochina-Barrachina M.E. 2007. Selection correction in panel data models: An application to the estimation of females' wage equation. Econometrics Journal 10, 263--293.

Faber J., Hensen A. 2004. Innovation capabilities of European nations - Cross-national analysis of patents and sales of product innovations. Research Policy 33, 193-207.

Gallié E.P, Legros D. 2012. Firms' human capital, R\&D and innovation: a study on French firms. Empirical Economics 43, 581-596.

García M., Burns J. 1999. Sources of technological development in the Spanish food \& drink industry: A `Supplier-dominated' industry. Agribusiness 15, 431-448.

Gopinath M., Vasadava U. 1999. Patents, R\&D, and market structure in the U.S. food processing industry. Journal of Agricultural and Resource Economics 24: 127-139.

Grunert K., Harmsen H., Meulenberg M., Kuiper E., Ottowitz T., Declerck F., Traill B., Goransson G. 1997. A framework for analysing innovation in the food sector. In B. Traill, \& K. G. Grunert (Eds.), Product and process innovation in the food sector. London: Blackie Academic.

Hall B. 2011. Innovation and productivity, NBER Working paper No. 17178.

Hall B., Harhoff D. 2012. Recent research on the economics of patents, NBER Working Paper No. 17773.

Hall B., Helmers C., Rogers M., Sena V. 2013. The importance (or not) of patents to UK firms. Oxford Economic Papers 65, 603-629. 
Horwitz F., Heng C., Quazi H. 2003. Finders, keepers? Attracting, motivating and retaining knowledge workers. Human Resource Management Journal 13, 23--44.

Huiban J., Boushima Z. 1998. Innovation and the quality of labour factor: An empirical investigation in the French food industry. Small Business Economics 10: 389-400.

de Jong J., Vermeulen P. 2006. Determinants of product innovations in small firms. A comparison across industries. International Small Business Journal 24, 587-609.

Karantininis K., Sauer J., Furtan W. 2011. Innovation and integration in the agri-food industry. Food Policy 35, 112-120.

Kanwar S., Evenson R. 2003. Does intellectual property protection spur technological change? Oxford Economic Papers 55, 235-264.

Licht G., Zoz K. 2000. Patents and R\&D - An econometric investigation using applications for German, European and US Patents by German companies, in: Encaoua, D; B. Hall, F. Laisney, J. Mairesse, The economics and econometrics of innovation, 307--338.

Mansfield E. 1986. Patents and innovation: an empirical study. Management Science 32, 173181.

Menrad K. 2004. Innovations in the food industry in Germany. Research Policy 33, 845-878.

Min Y., Agresti A. 2005. Random Effect Models for Repeated Measures of Zero-Inflated Count Data. Statistical Modelling 5, 1-19.

Moser P. 2012. Innovation without Patents: Evidence from World's Fairs. Journal of Law and Economics 55, 43--74.

Nagaoka S. Motohashi K., Goto A. 2010. Patent Statistics as an Innovation Indicator, in B. Hall and N. Rosenberg (eds.). Handbook of the Economics of Innovation, Elsevier.

Narula R., Zanfei A. 2003. Globalisation of Innovation The Role of Multinational Enterprises. DRUID Working Papers 03-15, Copenhagen Business School.

Pajak Serge. 2010. Do innovative firms rely on big secrets? An analysis of IP protection strategies with the CIS 4 survey. Mimeo, ENST Telecom ParisTech.

Pavitt K. 1984. Sectoral pattern of technological change: towards a taxonomy and theory. Research Theory 13, 343-373.

Peeters C., Van Pottelsberghe B. 2006. Innovation strategy and the patenting behavior of firms. Journal of Evolutionary Economics 16, 109-135.

Peneder M. 2007. Entrepreneurship and Technological Innovation. Austrian Institute for Economic Research (WIFO), Vienna.

Roper S., Hewitt-Dundas N.. 2008. Innovation persistence: Survey and case study evidence. Research Policy 37, 149-162.

Rubenstein K. 2003. Transferring Public Researc: The Patent Licensing Mechanism in Agriculture. Journal of Technology Transfer 28, 111-130. 
Sampath B., Ziedonis A. 2004. Patent Citations and the Economic Value of Patents: A Preliminary Assessment. In Handbook of Quantitative Science and Technology Research, Henk Moed, and Wolfgang Glanzel, Ulrich Schmoch, eds., Kluwer, Academic Publishers: Boston, MA.

Sanyang S., Kao T., Haung W. 2009. Comparative study of sustainable and non-sustainable interventions in technology development and transfer to the women's vegetable gardens in the Gambia. Journal of Technology Transfer 34, 59-75.

Staub K., Winkelmann S. 2013. Consistent estimation of zero-inflated count models. Health Economics 22, 673-686.

Sutton J. 2012. Competing in capabilities: the globalization process. Oxford University Press.

Un C., Cuervo-Cazurra, A. 2008. Do subsidiaries of foreign MNEs invest more in R\&D than domestic firms? Research Policy 37, 1812-1828.

Van Beveren I., Vanormelingen S. 2014. Human capital, firm capabilities and productivity growth. Working Paper Research 257, National Bank of Belgium

Vancauteren M., Melenberg B., Plasmans J., Bongard R. 2015. Innovation and productivity of Dutch firms: A panel data analysis. Mimeo, Tilburg University.

van Galen M., Logatcheva K., Bakker, T., Oosterkamp E., Jukema G. 2013. Innovatie in de levensmiddelenindustrie. Lei rapport 2103-036, Lei Wageningen, the Hague.

Weiss C., Wittkopp A. 2005. Retailer concentration and product innovation in food manufacturing. European Review of Agricultural Economics 32, 219-244.

Wijnands J., van der Meulen H., Poppe K. 2007. Competitiveness of the European food industry: An economic and legal assessment 2007. Office for Official Publications of the European Communities. Luxembourg.

Wooldridge J. 1995. Selection corrections for panel data models under conditional mean independence assumptions. Journal of Econometrics 68, 115--132.

Wooldridge J. 2005. Simple solutions to the initial conditions problem in dynamic, nonlinear panel data models with unobserved heterogeneity. Journal of Applied Econometrics 20, 39--54. 


\section{Appendix}

Table A1: Sample Means and Standard Deviations

\begin{tabular}{|l|l|l|l|}
\hline & $\begin{array}{l}\text { EPO \& Dutch patent } \\
\text { firms } \\
\text { (n=320, firm-years) } \\
\text { Mean (St.Dev.) }\end{array}$ & $\begin{array}{l}\text { EPO only } \\
\text { patent firms } \\
\text { (n=171, firm-years) } \\
\text { Mean (St.Dev.) }\end{array}$ & $\begin{array}{l}\text { Dutch only } \\
\text { patent firms } \\
\text { (n=243, firm-years) } \\
\text { Mean (St.Dev.) }\end{array}$ \\
\hline EPO patent applications & $7.086(34.146)$ & $2.421(6.125)$ & 0 \\
\hline Dutch patent applications & $1.075(3.154)$ & 0 & $0.573(2.607)$ \\
\hline R\&D (M euro) & $8.856(22.759)(\mathrm{n}=144)$ & $5.469(10.291)(\mathrm{n}=75)$ & $4.659(3.086)(\mathrm{n}=95)$ \\
\hline D (product) & $0.768(0.424)$ & $0.820(0.386)$ & $0.703(0.417)$ \\
\hline D (process) & $0.756(0.420)$ & $0.611(0.499)$ & $0.621(0.487)$ \\
\hline D (organization) & $0.570(0.430)$ & $0.402(0.494)$ & $0.388(0.497)$ \\
\hline Employment & $1330.7(1778.9)$ & $1061.319(1717.024)$ & $268.507(230.691)$ \\
\hline Wages (M euro) & $57.299(69.784)$ & $57.123(76.452)$ & $11.938(13.493)$ \\
\hline Herfindahl & $0.018(0.023)$ & $0.014(0.022)$ & $0.003(0.003)$ \\
\hline D (foreign) & $0.340(0.474)$ & $0.444(0.498)$ & $0.596(0.491)$ \\
\hline Ratio high/low skills & $1.156(1.310)$ & $1.026(1.223)$ & $0.608(1.412)$ \\
\hline \# activities & $3.085(3.069)$ & $3.395(3.165)$ & $2.317(2.356)$ \\
\hline \# subsidiaries & $5.889(9.271)$ & $5.697(8.628)$ & $2.827(2.899)$ \\
\hline
\end{tabular}

